\title{
Assessment of toxic potential of three different heavy metals to Clarias batrachus (Linn.) utilizing static acute bioassay
}

\author{
S.S. Gandhewar ${ }^{*}$, S.B. Zade $^{2}$ and S.R. Sitre \\ ${ }^{1}$ J.B. College of Science, Wardha (M.S.), INDIA \\ ${ }^{2}$ P.G. Department of Zoology, R.T.M. Nagpur University Campus, Amravati Road, Nagpur- 440033 (MS), INDIA \\ ${ }^{3}$ N.S. Science and Arts College, Bhadrawati, District Chandrapur-442902 (M.S.), INDIA \\ *Corresponding author. E-mail: ssgandhewar2007@ rediffmail.com
}

Received: November 12, 2013; Revised received: February 3, 2014; Accepted: April 4, 2014

\begin{abstract}
Acute toxicity bioassay of three different heavy metals copper $(\mathrm{Cu})$, lead $(\mathrm{Pb})$ and cadmium $(\mathrm{Cd})$ for the freshwater catfish, Clarias batrachus were conducted for evaluation of the toxicity. The $96 \mathrm{~h} \mathrm{LC}_{50}$ values recorded for $\mathrm{Cu}, \mathrm{Pb}$ and $\mathrm{Cd}$ were $15 \mathrm{ppm}, 29 \mathrm{ppm}$ and $35 \mathrm{ppm}$ respectively. The results of this study indicate that the order of toxicity of these heavy metals is $\mathrm{Cu}>\mathrm{Pb}>\mathrm{Cd}$ in short duration acute toxicity experiments. The toxicity was found to be dependent on dose and duration of experiment for all these heavy metals. Cu was found to be much more toxic than $\mathrm{Pb}$ and $\mathrm{Cd}$ to $C$. batrachus.
\end{abstract}

Keywords: Acute toxicity, Cadmium, Copper, LC $_{50}$, Lead

\section{INTRODUCTION}

The human efforts to increase production of food, energy and luxury things to enhance the standard of living resulted in increased industrialization, urbanization and rapid development. Heavy metals and other pollutants do not enter the aquatic environment as single entity, but are released in complex form (Olojo et al., 2005 ). The concern for environmental protection with respect to the aquatic environment arises from the fact that, various chemicals are discharged into surface water bodies which subsequently disturb their fragile ecology. As a result, several sensitive species are lost from the nature resulting in depletion of valuable biodiversity. Various non-biodegradable xenobiotics present in the industrial effluents get bound to sediments, animal and plant tissues and continue to exert their toxic effect due to slow release of toxicants (Adham et al., 2002; Olojo et al., 2005).

Aquatic ecosystems are sensitive to exposure of toxic contaminants and heavy metals. Among the aquatic organisms, fish is most vulnerable to these contaminants (Alinnor, 2005). Lead is a naturally occurring heavy metal present in the earth's crust, rocks, soil and water. Most water borne lead is derived from human activities such as mining, smelting, coal burning, cement manufacturing, use of gasoline, batteries and paint (Ramesh et al., 2009). Cadmium is one of the most toxic and widespread heavy metal and is a recognized carcinogen in mammals (Pruski and Dixon, 2002). Cadmium has become the focus of global research due to its toxicity to terrestrial and aquatic organisms while copper also acts as a potent toxin in aquatic organisms, when it enters into aquatic ecosystems. In this context toxicity of $\mathrm{Cu}, \mathrm{Pb}$ and $\mathrm{Cd}$ to freshwater catfish C. batrachus was assessed in short duration acute toxicity experiments in order to conserve and protect the freshwater catfishes in natural aquatic ecosystems. The significance of the present study lies in the fact of conservation and protection of aquatic biota which is useful as a food factor for the man in long run which is to be protected on top priority.

\section{MATERIALS AND METHODS}

Study material: 100 healthy fish weighing about 40 - $45 \mathrm{gm}$. were procured from natural unpolluted sources reservoir and brought to the laboratory, examined for any pathological symptoms, treated with $0.1 \%$ $\mathrm{KMnO}_{4}$ solution to avoid any dermal infection and acclimatized in dechlorinated tap water for 15 days. The fishes were fed on minced goat liver and tubifex worms once in a day in morning hours. The test fishes were selected and maintained in separate aquaria before actual experimentation.

Preparation of metal solution: The three different heavy metal salts viz. copper sulphate $\left(\mathrm{CuSO}_{4} .5 \mathrm{H}_{2} \mathrm{O}\right)$, lead acetate $\left(\mathrm{Pb}\left(\mathrm{C}_{2} \mathrm{H}_{3} \mathrm{O}_{2}\right)_{2}\right)$ and cadmium chloride $\left(\mathrm{CdCl}_{2}\right)$ (A.R.Grade) were selected for toxicological experiments. Dechlorinated tap water which was stored in a large overhead tank for about ten days was used for conducting the toxicity experiments. The physico-chemical characteristics of the dechlorinated tap water were determined as per standard methods 


\begin{tabular}{llc}
\hline S.N. & $\begin{array}{l}\text { Physico-chemical characteris- } \\
\text { tics of dilution water }\end{array}$ & Range \\
\hline 1 & $\mathrm{pH}$ & $7.2-7.4$ \\
2 & Temperature $\left({ }^{\circ} \mathrm{C}\right)$ & $24-28$ \\
3 & Dissolved Oxygen $(\mathrm{DO})(\mathrm{mg} / \mathrm{l})$ & $6.9-7.1$ \\
4 & Alkalinity $\left(\right.$ as $\left.\mathrm{CaCO}_{3}\right)(\mathrm{mg} / \mathrm{l})$ & $160-170$ \\
5 & Total hardness $\left(\mathrm{as} \mathrm{CaCO}_{3}\right)(\mathrm{mg} / \mathrm{l})$ & $160-180$ \\
\hline
\end{tabular}

(APHA, 2012). The details of the physico-chemical characteristics of water are given below:

Stock solution of the three heavy metals (copper sulphate, lead acetate and cadmium chloride) and their dilutions were made according to standard guidelines (OECD, 1981; APHA, 2012).

Experimental design and toxicity bioassay: In order to determine the $\mathrm{LC}_{50}$ of $\mathrm{CuSO}_{4} .5 \mathrm{H}_{2} \mathrm{O}, \mathrm{Pb}\left(\mathrm{C}_{2} \mathrm{H}_{3} \mathrm{O}_{2}\right)_{2}$ and $\mathrm{CdCl}_{2}$ (A.R.Grade) and their combination, method of Litchfield and Wilcoxon (1949) was followed. Successive batches of 10 fishes were exposed to different concentrations of heavy metals under standard laboratory conditions after $24,48,72$ and 96 hrs. duration. After specified time interval, the number of fish dead and alive were noted (Sprague, 1969). The experiments were carried out in glass aquaria of $100 \mathrm{~L}$ capacity in static laboratory conditions.

\section{RESULTS AND DISCUSSION}

The percent mortality observed for each dose was calculated and converted to probits by means of a probit table. Dosage versus percent mortality was plotted on the graph. The $\mathrm{LC}_{50}$ values and the $95 \%$ confidence limits of heavy metals, copper sulphate, lead acetate and cadmium chloride for fish, $C$. batrachus during 24, 48, 72 and $96 \mathrm{hrs}$ are presented in table 1 . The toxicity tolerance of freshwater fish $C$. batrachus to $\mathrm{CuSO}_{4} .5 \mathrm{H}_{2} \mathrm{O}, \mathrm{Pb}\left(\mathrm{C}_{2} \mathrm{H}_{3} \mathrm{O}_{2}\right)_{2}$ and $\mathrm{CdCl}_{2}$ in the present investigation are dose and duration dependent. It was noticed that mortality increased with an increase in concentration. $\mathrm{LC}_{50}$ values of all the three heavy metals as well as their combination showed the susceptibility of catfish to lethal concentrations in acute short term exposure.

Higher percent mortality occurred in the fish Clarias

Table 1. $\mathrm{LC}_{50}, 95 \%$ confidence limits and slope function values of $\mathrm{Cu}$ to $C$. batrachus in acute toxicity bioassay.

\begin{tabular}{|c|c|c|c|c|}
\hline \multirow{2}{*}{$\begin{array}{l}\text { Exposure } \\
\text { Period } \\
\text { (hrs.) }\end{array}$} & \multirow{2}{*}{ Parameter } & \multicolumn{3}{|c|}{ Values } \\
\hline & & Copper & Lead & Cadmium \\
\hline \multirow{4}{*}{24} & $\mathrm{LC}_{50} \mathrm{mg} / \mathrm{L}$ & 25 & 42 & 54 \\
\hline & $\begin{array}{l}95 \% \text { confidence } \\
\text { interval }\end{array}$ & $20.40-30.60$ & $33.60-52.50$ & $44.32-64.00$ \\
\hline & Slope function & $y=15.35 x-14.28$ & $y=13.16 x-12.5$ & $y=14.04 x-20.71$ \\
\hline & Regression $\left(\mathrm{R}^{2}\right)$ & 0.979 & 0.963 & 0.969 \\
\hline \multirow{4}{*}{48} & $\mathrm{LC}_{50} \mathrm{mg} / \mathrm{L}$ & 20 & 37 & 44 \\
\hline & $\begin{array}{l}95 \% \text { confidence } \\
\text { interval }\end{array}$ & $16.39-24.40$ & $29.13-46.99$ & $34.37-56.32$ \\
\hline & Slope function & $y=15.35 x-14.28$ & $y=10.5 x-13.61$ & $y=13.33 x-20$ \\
\hline & Regression $\left(\mathrm{R}^{2}\right)$ & 0.979 & 0.989 & 0.982 \\
\hline \multirow{4}{*}{72} & $\mathrm{LC}_{50} \mathrm{mg} / \mathrm{L}$ & 17.50 & 34 & 40 \\
\hline & $\begin{array}{l}95 \% \text { confidence } \\
\text { interval }\end{array}$ & $14.30-21.35$ & $26.56-43.52$ & $34.18-46.80$ \\
\hline & Slope function & $y=13.21 x+2.857$ & $y=11.33 x-22.22$ & $y=11.78 x-21.78$ \\
\hline & Regression $\left(\mathrm{R}^{2}\right)$ & 0.910 & 0.960 & 0.958 \\
\hline \multirow{4}{*}{96} & $\mathrm{LC}_{50} \mathrm{mg} / \mathrm{L}$ & 15 & 29 & 35 \\
\hline & $\begin{array}{l}95 \% \text { confidence } \\
\text { interval }\end{array}$ & $10.59-20.50$ & $21.46-39.15$ & $23.30-52.50$ \\
\hline & Slope function & $y=15.35 x+0.00$ & $y=9.66 x-21.66$ & $y=11.78 x-21.78$ \\
\hline & Regression $\left(\mathrm{R}^{2}\right)$ & 0.932 & 0.934 & 0.958 \\
\hline
\end{tabular}


batrachus, under investigation with increase in concentration and exposure period, which confirms the similar observations recorded by researchers worldwide such as in case of Oncorhynchus mykiss, Salvelinus confluentus and Oncorhynchus tshawytscha (Finalayson and Verrue, 1982; Hansen et al., 2002), guppy, Poecilia reticulata (Yilmaz et al., 2004), Cyprinus carpio (Muley et al., 2000; Dardenne et al., 2007), Nile tilapia, Oreochromis niloticus (Garcia et al., 2006) and Rohu, Labeo rohita (Dutta and Kaviraj, 2001).

In the present research work, Finney's Probit Analysis for evaluating the acute toxicity response gave 96 hour $\mathrm{LC}_{50}$ value for $C$. batrachus exposed to $\mathrm{CuSO}_{4} \cdot 5 \mathrm{H}_{2} \mathrm{O}$ as $15 \mathrm{ppm}, \mathrm{Pb}\left(\mathrm{C}_{2} \mathrm{H}_{3} \mathrm{O}_{2}\right)_{2} 29 \mathrm{ppm}, \mathrm{CdCl}_{2} 35 \mathrm{ppm}$. From the derived $\mathrm{LC}_{50}$ values, it is quite clear that, the toxic effect increased with dose and duration. Our results are in agreement with Yilmaz et al. (2004) who reported $96 \mathrm{~h} \mathrm{LC}_{50}$ value of cadmium to guppy $(P$. reticulata). The other supporting studies are of Oryan and Nejatkhah (1997), Woodal et al. (1988) and Muley et al. (2000).

Today, worldwide heavy metals are introduced into aquatic environment through industrial processes, soil leaching, mining activities, sewage disposal and rainfall. The heavy metals are relatively toxic, even at fairly low concentrations and affect the survival of all other aquatic organ-isms. Stebbing and Fandino (1983) reported that, the adverse biological effects of heavy metals in the aquatic environment are mainly due to their complex nature. When the toxicant concentration in the water body is very high, it results in the death of fish. So, the death of an organism was taken as the end point of toxicological studies previously (Jones and Reynolds, 1997). However, Adams (1990) stated that sublethal concentrations of toxicant also induce substantial changes in the biological organization of fish.

The $\mathrm{LC}_{50}$ values derived from toxicological investigations are highly useful in determining the sublethal concentration of a metal. Today, most of the information on the effects of heavy metals on aquatic organisms is focused on short duration experiments carried out at lethal concentrations. The information thus derived is not sufficient to assess the extent of damage. Hence, there is a need to carry out studies related to sublethal toxicity. Such studies are highly valuable in evaluating the sequence of events that involve the response of the test animal to sublethal concentrations (Nobbs and Pearu, 1976; Perkin, 1979). So, in order to derive sublethal concentrations and to evaluate the response of the fish at sublethal concentrations, $\mathrm{LC}_{50}$ values are of prime importance in today's changing scenario of environmental pollution.

\section{Conclusion}

The present toxicological investigation clearly showed that the toxicity is dose and duration dependent for all the three heavy metals. The heavy metal $\mathrm{Cu}$ was much more toxic than $\mathrm{Pb}$ and $\mathrm{Cd}$. The mortality increased with an increase in concentration and $\mathrm{LC}_{50}$ values of all these heavy metals showed the susceptibility of catfish to lethal concentrations in acute short term exposure. Such type of toxicological studies will be useful for conservation and protection of aquatic organisms and ultimately safeguarding the interest of man in long run as a food supply.

\section{REFERENCES}

Adams, S.M. (1990). Status and use of biological indicators for evaluating the effects of stress of fish. In: Biological indicators of stress in fish. pp, 1-8, Fisheries Society, Bethseda, Maryland.

Adham, K.G., Hameed, S.S., Ibrahim, H.M. and Saleh, R.A. (2002). Impaired functions in nile tilapia, Oreochromis niloticus (Linnaeus), from Polluted Waters. Acta Hydrochem. Hydrobiol., 29(5): 278-288.

Alinnor, I. (2005). Assessment of elemental contaminants in water and fish samples from Aba river. Environ. Monit. Assess., 102: 15-25.

APHA, AWWA, WEF (2012). Standard methods for the examination of water and wastewater, $22^{\text {nd }}$ Edition, Washington, D.C.

Dardenne, F., Novels, I., De, C.W. and Blust, R. (2007). Dose-response relationships and statistical performance of a battery of bacterial gene profiling assays. App. Mcirobiol. Biotechnol., 75(1): 223-234.

Dutta, T.K. and Kaviraj, A. (2001). Acute toxicity of cadmium to fish Labeo rohita and copepod Diaptomus forbesi Pre-Exposed to $\mathrm{CaO}$ and $\mathrm{KMnO}_{4}$. Chemosphere, 42(8): 919-922.

Finalayson, B.J. and Verrue, K.M. (1982). Toxicities of copper, zinc and cadmium mixtures of juvenile Chinook salmon. Trans. Amer. Fish. Soc., 111: 645-650.

Garcia, S., Fontainhas-Fernandes, A. and Wilson, J.M. (2006). Cadmium tolerance in the Nile tilapia (Oreochromis niloticus) following acute exposure: assessment of some ionoregulatory parameters. Environ. Toxicol., 21(1):33-46.

Hansen, J.A., Welsh, P.G., Lipton, L. and Suedkamp, M.J. (2002). The effects of long-term cadmium exposure on the growth and survival of juvenile bull trout (Salvelinus confluentus). Aquat Toxicol., 58(3-4): 165-174.

Jones, J.C. and Reynolds, J.D. (1997). Effects of pollution of reproductive behavior of fishes. Rev. Fish Biol. Fisheries, 7: 463-491.

Litchfield, J.T. Jr. and Wilcoxon, F. (1949). A simplified method for evaluating dose effect experiments, $J$. Pharm. Exp. Ther., 96: 99-113.

Muley, D.V., Kamble, G.B. and Bhilave, M.P. (2000). Effect of heavy metals on nucleic acids in Cyprinus carpio. $J$. Environ. Biol., 21: 367-370.

Nobbs, C.L. and Pearu, D.M. (1976). The economics of stock pollutants - The example of cadmium. Int. Environ. Stu., 8: 245-255.

OECD ( 1981). Guidelines for testing of chemicals, Section2. "Effects on biotic systems Test 201", Algal Growth Inhibition Test, Paris.

Olojo, E.A.A., Olurin, K.B., Mbaka, G. and Oluwemimo, A.D. (2005). Histopathology of the gill and liver tissues of the African catfish Clarias gariepinus exposed to lead. Afr. J. Biotech., 4(1): 117-122.

Oryan, S. and Nejatkhah, P. (1997). Effects of cadmium on plasma cortisol and prolactin levels in the rainbow trout (Oncorhynchus mykiss). J. Fac. Vet. Med. Univ. Te- 
hran., 51: 39-53.

Perkin, E.J. (1979). Need for sublethal studies. Phil. Trans. R. Soc. London B., 286: 425-432.

Pruski, A.M. and Dixon, D.R. (2002). Effects of cadmium on nuclear integrity and DNA repair efficiency in the gill cells of Mytilus edulis L. Aquat. Toxicol., 57(3): 127137.

Ramesh, M., Saravanan, M. and Kavitha, C. (2009). Hormonal responses of the fish, Cyprinus carpio, to environmental lead exposure. African J. Biotechnol., (17):41544158.

Sprague,J.B. (1969). Measurement of Pollutant Toxicity to Fish : I , Bioassay Methods for Acute Toxicity. Water
Research, $3: 793-821$.

Stebbing, A.R.D. and Fandino, V.J.R.S. (1983). The combined and separate effects of copper and cadmium on the growth of Campenularia flexuosa colonies (Hydrozoa). Aquatic Toxicology, 3: 183-193.

Woodal, C., Maclean, N. and Crossley, F. (1988). Responses of trout fry (Salmo gairdneri) and Xenopus laevis tadpoles to cadmium and zinc. Compar. Biochem. Physiol., 89: 93-99.

Yilmaz, M., Gul, A. and Karakose, E. (2004). Investigation of acute toxicity and the effect of cadmium chloride $\left(\mathrm{CdCl}_{2} \cdot \mathrm{H}_{2} \mathrm{O}\right)$ metal salt on behavior of the guppy (Poecilia reticulata). Chemosphere, 56: 375-380. 